\title{
Wireless Personal Area Network Performance Evaluation on Driving Simulator Realization
}

\author{
LISA KRISTIANA, AFRIZAL MAULANA MUHAMMAD
}

Program Studi Informatika Institut Teknologi Nasional Bandung, Indonesia

Email : lisa@itenas.ac.id

Received 12 September 2021 | Revised 6 November 2021 | Accepted 30 November 2021

\begin{abstract}
ABSTRAK
Berdasarkan hukum Indonesia, dijelaskan bahwa setiap orang yang mengemudikan kendaraan bermotor wajib memiliki Surat Izin Mengemudi (SIM) yang dapat diperoleh dengan menggunakan simulasi mengemudi. Namun, banyak calon pengemudi yang gagal karena kurangnya pelatihan, seperti tidak ada lahan atau tidak memiliki kendaraan pribadi. Selain itu, pelatihan menggunakan simulasi tidak dapat dilakukan secara pribadi karena simulasi hanya berada di kantor kepolisian dan biaya instalasi yang mahal. NRF24LO1 adalah Wireless Personal Area Networks (WPAN) yang digunakan untuk penelitian ini karena cakupannya yang kecil tetapi kecepatan data yang tinggi. Tujuan dari penelitian ini adalah mengimplementasikan NRF24LO1 untuk simulasi mengemudi dan mengamati tingkat akurasi dan Quality of Service (QoS) terjadi pada simulasi wireless. Pengujian menunjukkan bahwa penghalang dan jarak antar transceiver dapat menurunkan tingkat akurasi dan QoS.
\end{abstract}

Kata kunci: simulasi menyetir, jaringan nirkabel, NRF24LO1, Wireless Personal Area Networks, Quality of Service.

\begin{abstract}
Based on Indonesian law, it is explained that everyone who drives a motorized vehicle is required to have a Driving License (SIM) which can be obtained by using a driving simulation. However, many prospective drivers fail due to lack of training, such as not having land or not owning a private vehicle. In addition, training using simulations cannot be carried out in person because the simulations only take place at the police station and the installation costs are expensive. NRF24LO1 is the Wireless Personal Area Networks (WPAN) used for this research because of its small coverage but high data rate. The purpose of this research is to implement NRF24LO1 for driving simulation and observe the level of accuracy and Quality of Service (QOS) occurring in the wireless simulation. Tests show that obstructions and distance between transceivers can reduce the level of accuracy and QoS.
\end{abstract}

Keywords: driving simulation, wireless networks, NRF24LO1, Wireless Personal Area Networks, Quality of Service. 


\section{INTRODUCTION}

Motorized vehicle is any vehicle that is driven by a machine (Article 1 paragraph (8) of Law No.22 of 2009 concerning Road Traffic and Transportation). There are still drivers who have not obeyed the regulations in Indonesia, such as not having or carrying a driving license or Surat Izin Mengemudi (SIM) when driving. Based on Indonesian law, it is explained that everyone who drives a motorized vehicle is required to have a driving license which can be obtained at Indonesian National Police (Polri) after passing all the existing requirements, i.e., to be at least 17 years old, pass written dan practical exams.

Practical exams conducted at the police station are in the form of using actual motorized vehicles and using simulations (Kurniadi, Yohan. Liliana \& Radion Purba, 2016). However, many participants failed the practical exam because there is no proper training and lack of facilities to practice driving, such as there is no place to practice and not owning a vehicle. In addition, training using simulations cannot be carried out in privately because the simulation is only at the police station and the installation costs are expensive (Desman $\mathbf{R}$. , Crisandolin., Hannats H.I., Mochammad, S.B., 2018).

Wireless networks or wireless networks can be used in the construction of driving simulations because wireless networks can communicate quickly, access easy use (Sumarjono, 2018), low installation costs and mobility (Lasagani, 2018). Wireless Personal Area Networks (WPAN) will be used in the construction of a driving test simulation model because it does not require a data transmission coverage that is too wide, which is 100 meters and requires low power, easy installation, and reliable data transfer (Ali \& Mouftah, 2011). WPAN is a wireless network that connects two or more devices using radio frequency channels as physical media with a limited area (Basak \& Sen, 2017). The transceiver module that will be used is NRF24L01 because this module has a high data rate (Kusriyanto \& Wismoyo, 2017), stability, accuracy (Fajriansyah, Ichwan, \& Susana, 2018), good performance of delay, throughput, availability, and reliability (Kurnia, Wisma D., Munadi, Rendy., Bisono, 2018).

However, the main problem in wireless network performance lies in the physical link, such as attenuation, distortion, noise (Rasudin, 2014), the number of receivers connected to the transmitter and the distance between the transceivers. When the distance between the transceivers is getting farther, the data transmission will be hampered. (Manru, Eko Prasetyo, 2016). So it is necessary to measure the quality of the wireless network using Quality of Service (QoS) measurements. QoS is the ability of a service to guarantee performance and is a parameter to measure the quality of a service (Wulandari, Pipit., Soim, Sopian., Rose, 2017). QoS parameters used for data communication service analysis are jitter, packet loss, throughput, and delay (Pranata, Fibriani, \& Utomo, 2016).

In this paper, Wireless Personal Area Networks (WPANs) will be applied to build and control a driving test simulation model, so that the driving test can be carried out wirelessly. In addition, this study was conducted to observe the Quality of Service (QoS) in the packet loss, delay, throughput, and jitter sections to determine the quality of wireless communication.

\section{RESEARCH METHOD}

\subsection{General Design}

$$
\text { MIND - } 206
$$


The driving simulation system consists of a steering gear and a simulated car that is controlled

wirelessly. Because it requires high efficiency, effectiveness, and the distance between the transceiver is $\leq 100$ meter, NRF24L01 are used (Fitri \& Setiawan, 2015). In this research, the NRF24L01 is divided into two parts, namely as a transmitter on the steering gear and a receiver in the simulated car. The general design of the system is shown in Figure 1

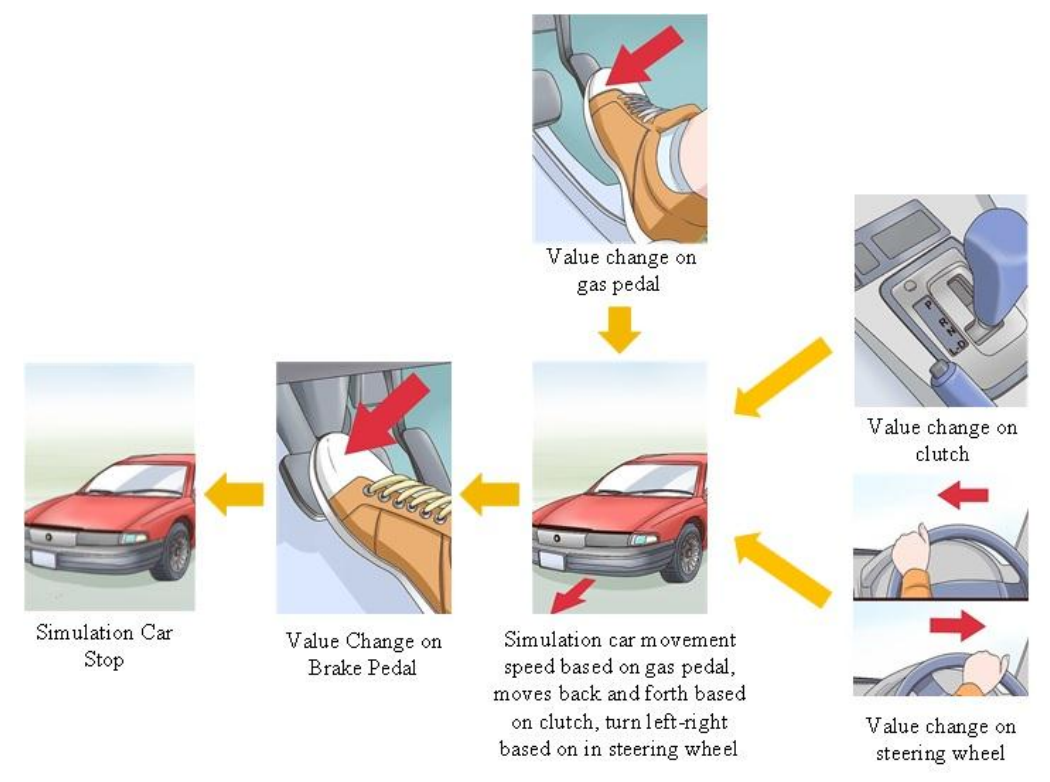

Figure 1. General Design

The system design that will be built will be divided into two separate parts, namely the design of the steering gear and the simulation car. The steering gear will be divided into four parts, namely the steering wheel, clutch, gas and brake pedals. The steering wheel will be connected with a rotary potentiometer. When the steering wheel is turned right or left, the simulation car will move right or left as well. While the gas and brake pedals will be given a sliding potentiometer. When the pedal is stepped on, the potentiometer value will increase and cause the simulation car to run faster, while when the brake pedal is stepped on, the rotational speed of the wheels becomes smaller so the car will stop. For the clutch will be connected with a toggle switch. When the clutch is changed its position causes a change in the direction of rotation of the wheel, i.e. forward or backward. The steering gear will be supplied with a voltage source from battery. The system built will be described in a flowchart for the steering gear shown in Figure 2. 


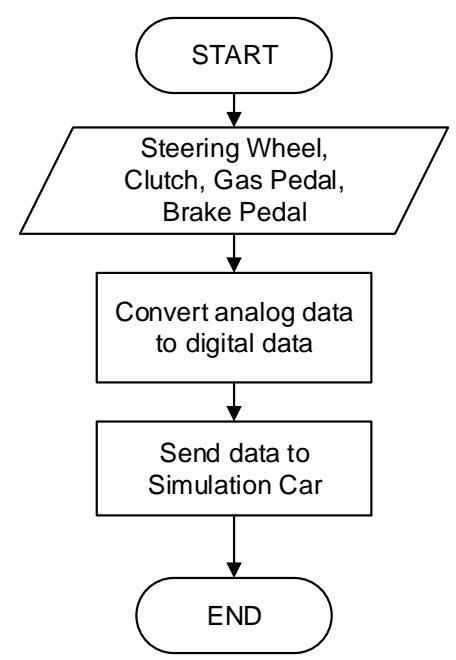

Figure 2. Flowchart for Steering Gear

Arduino Uno receives input data from a switch for the clutch, a rotary potentiometer for the steering wheel, and two slider potentiometers for the gas and brake pedals. Then, converting analog data from rotary potentiometer and slider potentiometer to digital data. Then, send data to the receiver wirelessly using NRF24L01. While the design of the simulation car will use a servo, four DC motors, four wheels, and L298N. Servo is used to adjust the direction of rotation of the car, DC motor is used to drive the wheels and L298N is used to adjust the rotation speed of the DC motor. The simulation car will be supplied with a voltage source from battery. The system built will be described in a flowchart for the simulation car shown in Figure 3. 

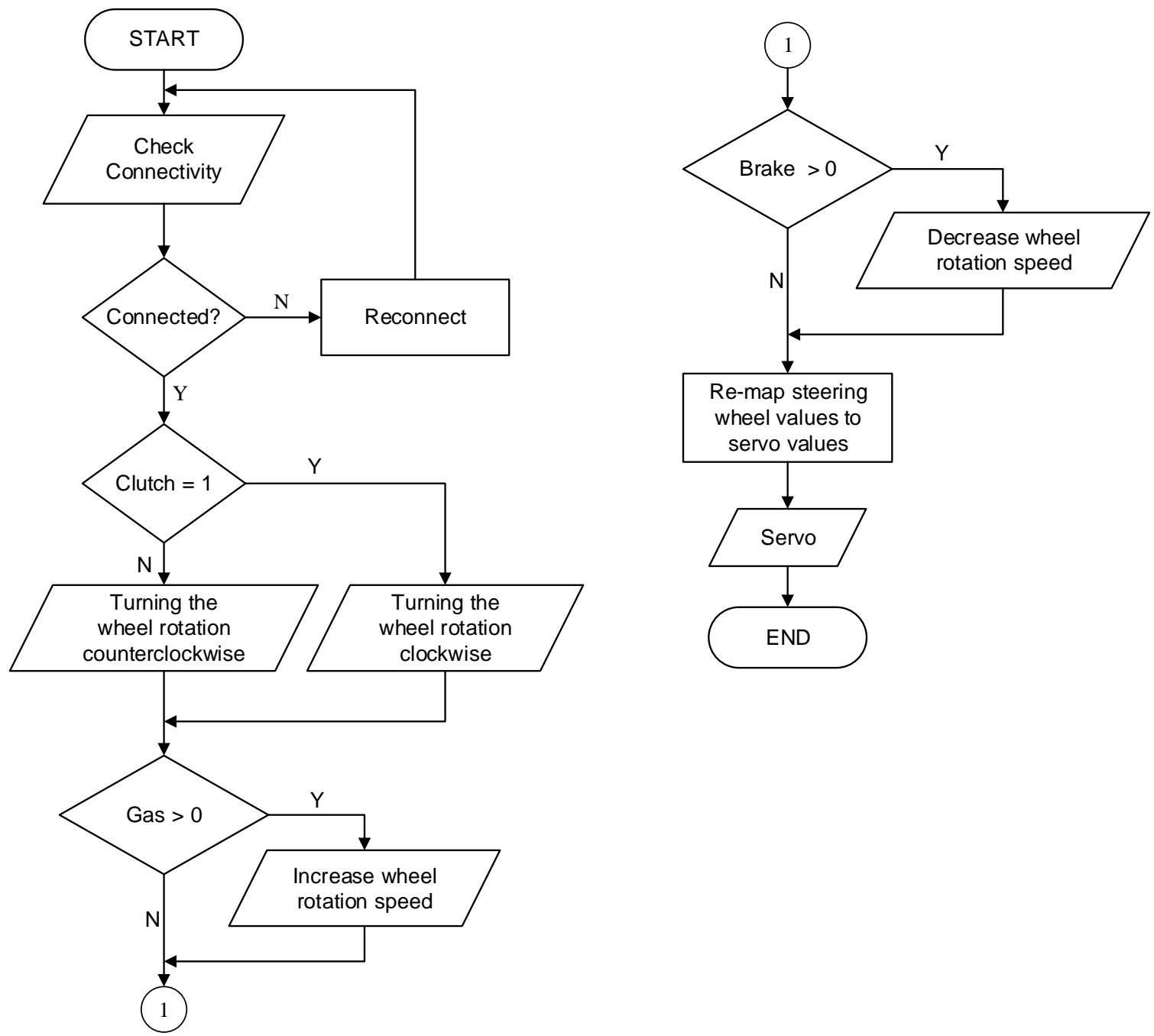

Figure 3. Flowchart for Simulation Car

Arduino Uno checking connectivity between transcievers. If not connected, then reconnect connectivity between transcievers. Then, if the switch value for the clutch is 1 (High), then the car wheels will rotate clockwise (forward). Otherwise, the car wheels will rotate counterclockwise (backwards). When the gas pedal is stepped on, the simulation car wheel speed will increase and vice versa if the brake pedal is stepped on, the simulated car wheel speed will decrease. After that, remap the value from the steering wheel to the servo value so that the servo movement can match the steering wheel movement.

\subsection{Prototype}

The prototype will be divided into two, namely a simulated car and a steering wheel. The simulation car is a tool that will be driven by the user in the driving simulator, while the steering tool is a tool that will be used by the user to control the simulated car wirelessly. Simulation cars will be built to resemble cars in general. The speed and direction of tire rotation will depend on user input given from the steering gear. The steering gear will consist of a steering wheel to change the direction of the car's speed, a clutch to change the direction of wheel rotation, the gas pedal to increase the rotational speed of the wheels, and the brake pedal to reduce the rotational speed of the simulated car wheels. The prototype of 
the steering gear is shown in Figure 4 and the prototype of the simulation car is shown in Figure 5.

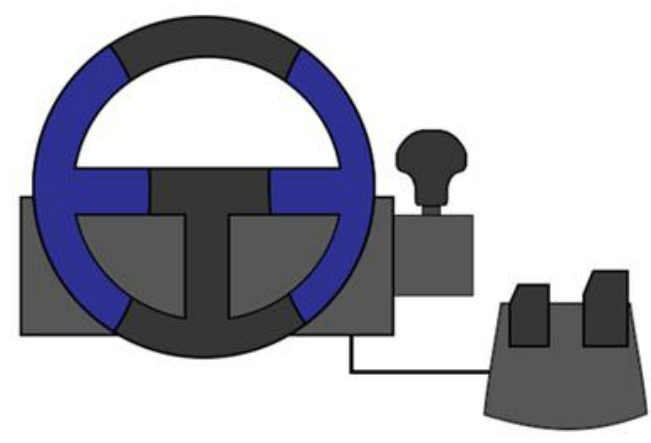

Figure 4. Prototype of Steering Gear

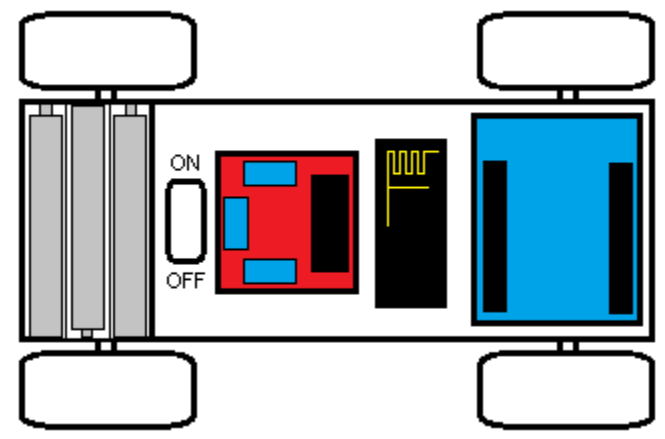

(a)

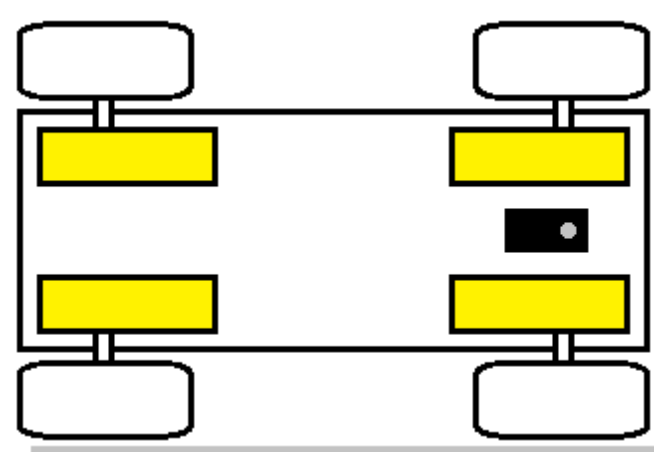

(b)

Figure 5. Prototype of Simulation Car (a) Top Views (b) Bottom Views

\subsection{Interconnection}

In the interconnection design for the steering wheel, the components used are a slider potentiometer connected to the gas pedal and brake pedal, a rotary potentiometer on the steering wheel, a toggle switch on the clutch, and the NRF24L01 is used as a transmitter to wirelessly transmit data to the simulated car. The interconnection of steering wheel used in this design is shown in Figure 6.

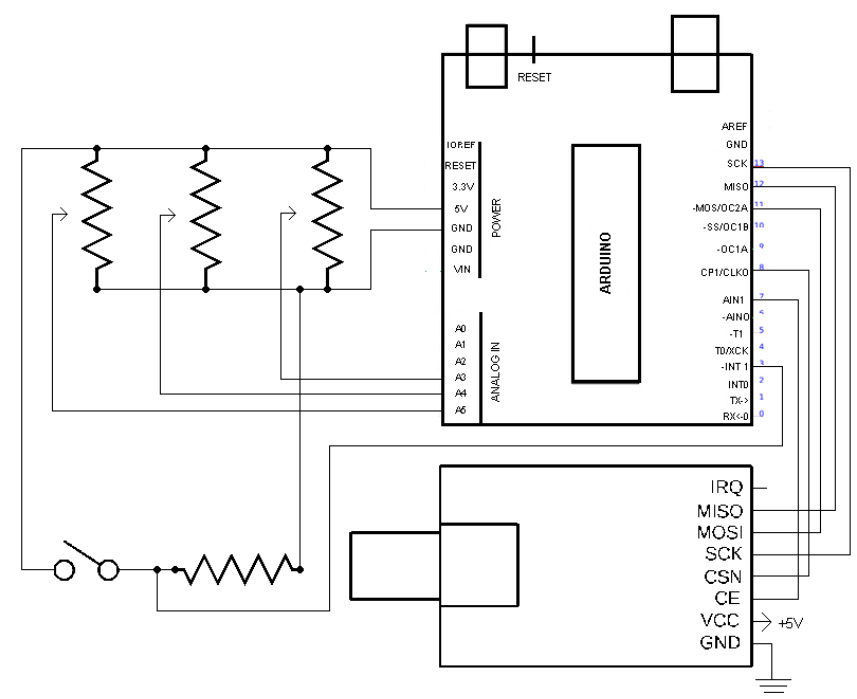




\section{Figure 6. Steering Gear Interconnection}

NRF24L01 will be connected to Arduino Uno on pin VCC at 5V voltage, ground pin, five digital

pins, namely CSN, CE, SCK, MOSI, and MISO. Then, two potentiometer sliders will be to the Arduino Uno on the $\mathrm{VCC}$ pin at $5 \mathrm{~V}$, the ground pin, and the input pin. A rotary potentiometer will be connected to the Arduino Uno on the VCC pin at 5V, the ground pin, and

the input pin. Last, a toggle switch will be connected to the Arduino Uno on the VCC pin at $5 \mathrm{~V}$, the ground pin, and the input pin.

For the simulated car, the components used are the L298N which is connected to four DC motors to control the speed and direction of rotation of the DC motor and the NRF24L01 is used as a receiver to receive data wirelessly from the steering gear. The interconnection of simulated car used in this design are shown in Figure 7.

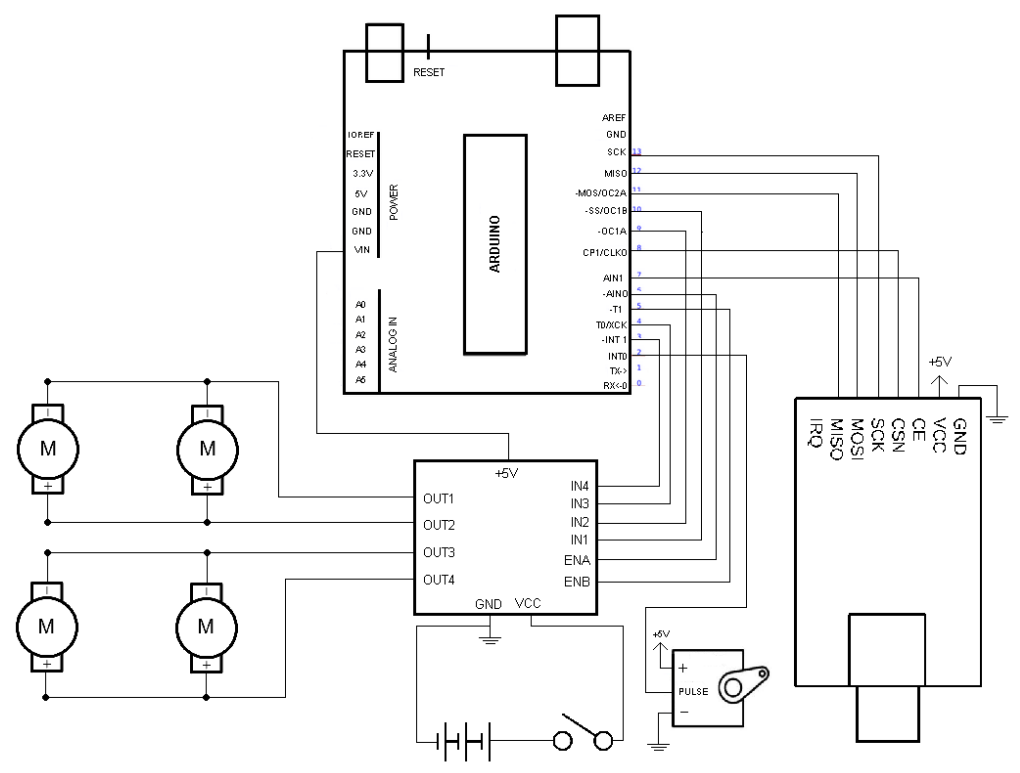

Figure 7. Simulated Car Interconnetion

NRF24L01 will be connected to Arduino Uno on VCC pin for 5V voltage, ground pin, five digital

pins, namely CSN, CE, SCK, MOSI, and MISO. A servo connected to the Arduino Uno on the VCC pin at 5V, the ground pin, and the input pin. Then, two DC motors connected to L298N at OUT1 \& OUT2 and two other DC motors connected to OUT3 \& OUT4. Last, L298N connected to Arduino Uno from $5 \mathrm{~V}$ to three 18650 batteries with a voltage of $3.7 \mathrm{~V}$, ground pin, VIN pin, and six input pins, namely IN1 \& IN2, IN3 \& IN4, ENA and ENB.

\section{RESULTS AND DISCUSSION}

\subsection{Implementation}

Performance testing will be done by measuring the accuracy and the Quality of Service on wireless communication. The initial distance used for testing is 1 meter with an additional distance of 3 meter for each test until the simulation car cannot receive data. The test will be carried out indoors (at home) and outdoors (in the yard) as an indicator of the presence or 
absence of a obstructions. Indoor and outdoor test locations are shown in the Figure 8 . The battery used for each indoor or outdoor test will be replaced with several spare batteries that have been charged with a charging time of approximately 2 hours and the battery used is checked periodically every 1 hour. Battery replacement is done so that the data obtained can be consistent.

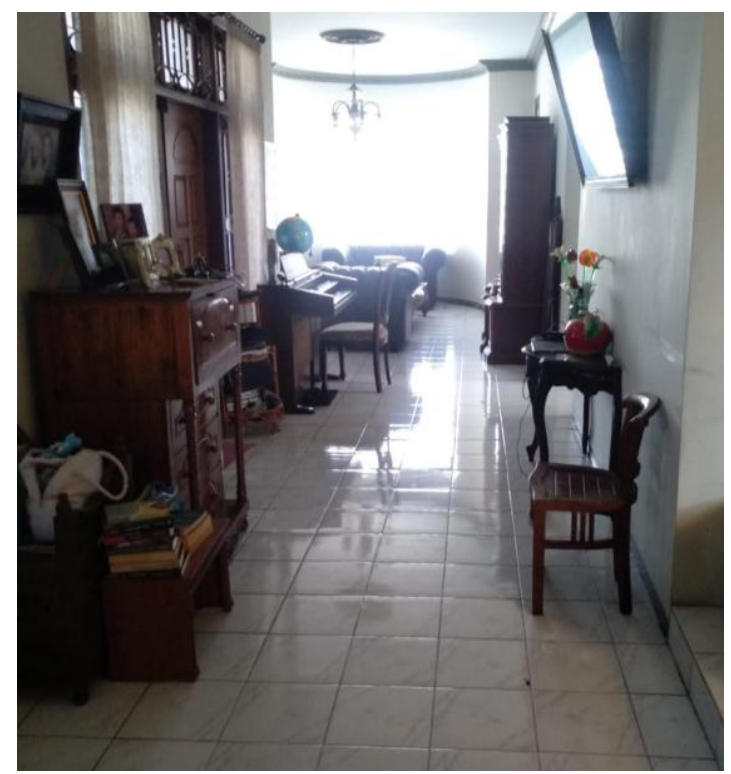

(a)

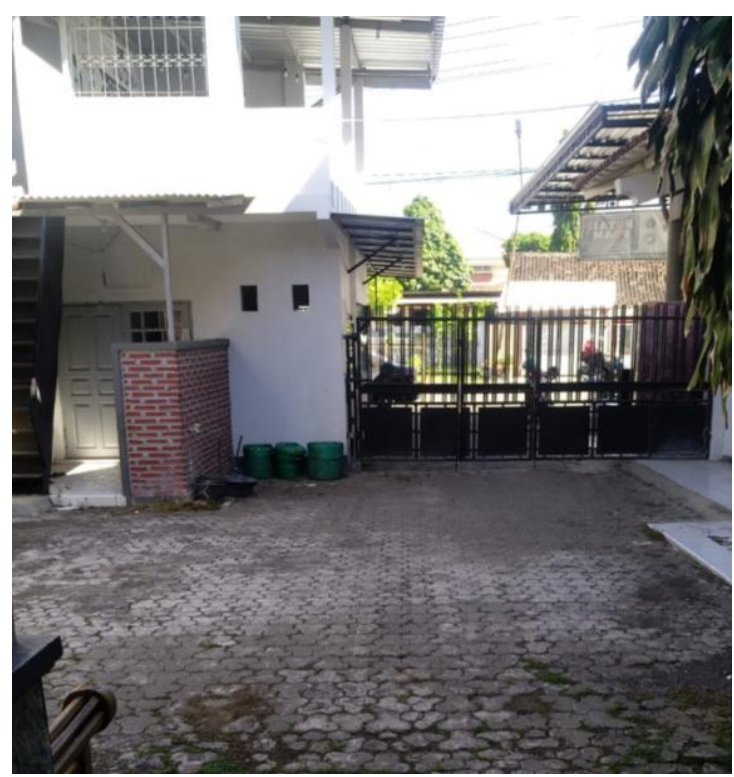

(b)

Figure 8. Test Locations (a) Indoor (b) Outdoor

The simulation car was built using plywood as the foundation. Arduino Uno, L298N, NRF24L01 and adapters, as well as batteries are placed on plywood. For the bottom of the plywood, there are servos and four DC motor gearboxes mounted with wheels. Figure 9 is a simulated car prototype for the front, top, and bottom views.

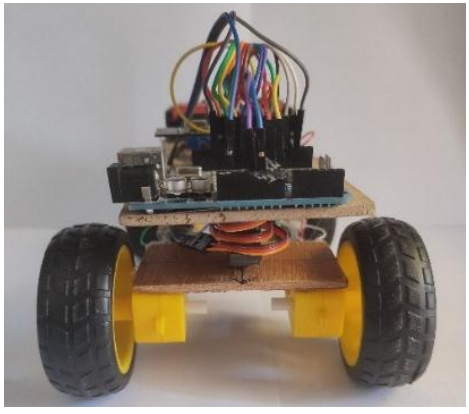

(a)

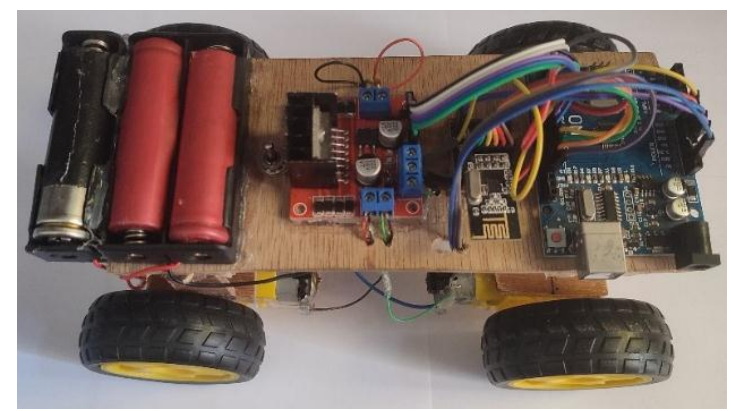

(b) 


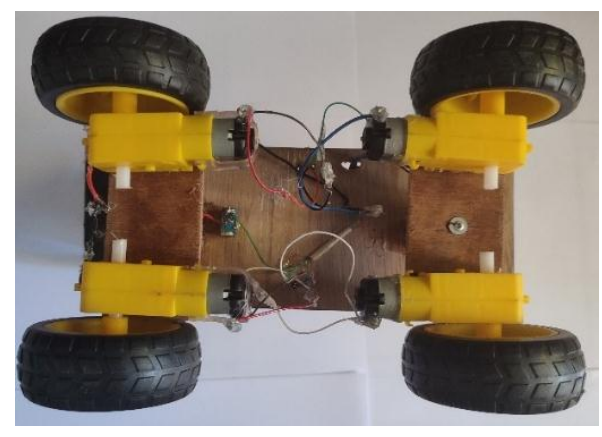

(c)

\section{Figure 9. Implementation of Simulation Car (a) Front Views (b) Top Views (c) Bottom} Views

The steering gear is built using plywood as the foundation for the steering wheel and clutch, and wood as the foundation for the gas and brake pedals. The rotary potentiometer is connected to another plywood which is used as a pole and steering wheel. The toggle switch is connected to a plastic that functions as a clutch handle. The slider potentiometer will be connected to the gas and brake pedals equipped with springs. Arduino Uno, breadboard, NRF24L01 and adapter, and battery are placed inside the steering gear. The gas and brake pedals are connected to the Arduino via a breadboard using cables. Figure 10 is the prototype

of steering gear. Index 1 is the steering wheel, index 2 is the clutch, index 3 is the gas pedal and index 4 is the brake pedal.

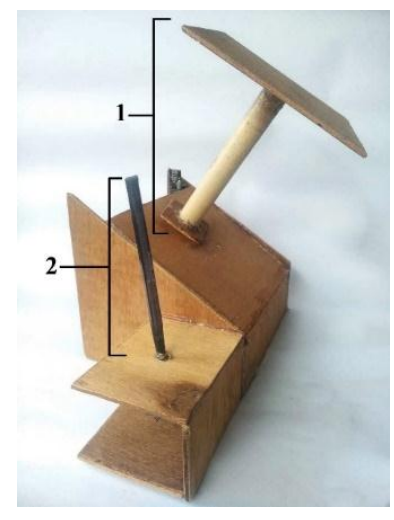

(a)

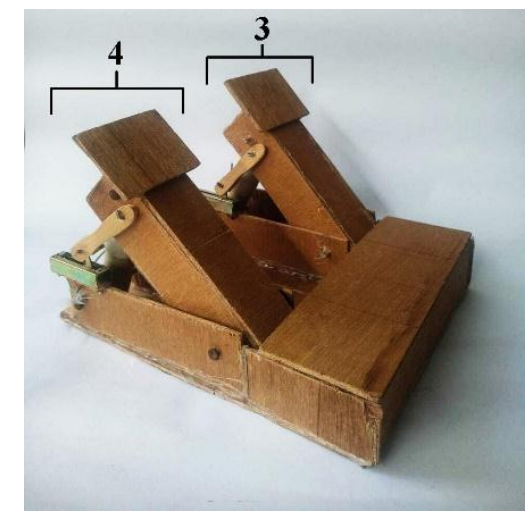

(b)

Figure 10. Implementation of Steering Gear (a) Steering Wheel and Clutch (b) Gas Pedal and Brake Pedal

Data retrieval is carried out using static testing, the amount of data that has been obtained will be analyzed for the level of accuracy and error to find out how much error is obtained in the data sent using Equation 1, then calculate the level of accuracy using Equation 2.

$$
\begin{aligned}
& \text { Error }=\frac{\text { Data Sent-Data Received }}{\text { Data Received }} \times 100 \% \\
& \text { Accuracy }=100 \%-\frac{\sum \text { Error }}{n}
\end{aligned}
$$

\subsection{Indoor Accuracy Test Results}


The results of the accuracy test for the indoor test are listed in Table 1, Table 2, and Table 3.

Table 1. Indoor Accuracy Test Result (Gas Test and Brake Test)

\begin{tabular}{|c|c|c|c|c|c|c|c|}
\hline \multicolumn{4}{|c|}{ Gas Test } & \multicolumn{4}{|c|}{ Brake Test } \\
\hline $\begin{array}{l}\text { Distance } \\
\text { (Meter) }\end{array}$ & Data Sent & $\begin{array}{c}\text { Data } \\
\text { Received }\end{array}$ & Error & $\begin{array}{l}\text { Distance } \\
\text { (Meter) }\end{array}$ & $\begin{array}{l}\text { Data } \\
\text { Sent }\end{array}$ & $\begin{array}{c}\text { Data } \\
\text { Received }\end{array}$ & Error \\
\hline 1 & 1000 & 1000 & $0,00 \%$ & 1 & 1000 & 1000 & $0,00 \%$ \\
\hline 2 & 1000 & 982 & $1,80 \%$ & 2 & 1000 & 989 & $1,10 \%$ \\
\hline 3 & 1000 & 960 & $4,00 \%$ & 3 & 1000 & 979 & $2,10 \%$ \\
\hline 4 & 1000 & 973 & $2,70 \%$ & 4 & 1000 & 999 & $0,10 \%$ \\
\hline 5 & 1000 & 963 & $3,70 \%$ & 5 & 1000 & 980 & $2,00 \%$ \\
\hline 6 & 1000 & 959 & $4,10 \%$ & 6 & 1000 & 981 & $1,90 \%$ \\
\hline 7 & 1000 & 956 & $4,40 \%$ & 7 & 1000 & 957 & $4,30 \%$ \\
\hline 8 & 1000 & 950 & $5,00 \%$ & 8 & 1000 & 951 & $4,90 \%$ \\
\hline 9 & 1000 & 948 & $5,20 \%$ & 9 & 1000 & 943 & $5,70 \%$ \\
\hline 10 & 1000 & 923 & $7,70 \%$ & 10 & 1000 & 904 & $9,60 \%$ \\
\hline 11 & 1000 & 910 & $9,00 \%$ & 11 & 1000 & 898 & $10,20 \%$ \\
\hline 12 & 1000 & 910 & $9,00 \%$ & 12 & 1000 & 873 & $12,70 \%$ \\
\hline 13 & 1000 & 0 & $100,00 \%$ & 13 & 1000 & 0 & $100,00 \%$ \\
\hline 14 & 1000 & 0 & $100,00 \%$ & 14 & 1000 & 0 & $100,00 \%$ \\
\hline \multicolumn{3}{|c|}{ Average error } & $4,72 \%$ & \multicolumn{3}{|c|}{ Average error } & $4,55 \%$ \\
\hline \multicolumn{3}{|c|}{ Gas Accuracy } & $95,28 \%$ & \multicolumn{3}{|c|}{ Brake Accuracy } & $95,45 \%$ \\
\hline
\end{tabular}

Table 2. Indoor Accuracy Test Result (Forward Test and Backward Test)

\begin{tabular}{|c|c|c|c|c|c|c|c|}
\hline \multicolumn{4}{|c|}{ Forward Test } & \multicolumn{4}{|c|}{ Backward Test } \\
\hline $\begin{array}{c}\text { Distance } \\
\text { (Meter) }\end{array}$ & Data Sent & $\begin{array}{c}\text { Data } \\
\text { Received }\end{array}$ & Error & $\begin{array}{c}\text { Distance } \\
\text { (Meter) }\end{array}$ & $\begin{array}{l}\text { Data } \\
\text { Sent }\end{array}$ & $\begin{array}{c}\text { Data } \\
\text { Received }\end{array}$ & Error \\
\hline 1 & 1000 & 1000 & $0,00 \%$ & 1 & 1000 & 1000 & $0,00 \%$ \\
\hline 2 & 1000 & 991 & $0,90 \%$ & 2 & 1000 & 988 & $1,20 \%$ \\
\hline 3 & 1000 & 968 & $3,20 \%$ & 3 & 1000 & 975 & $2,50 \%$ \\
\hline 4 & 1000 & 972 & $2,80 \%$ & 4 & 1000 & 984 & $1,60 \%$ \\
\hline 5 & 1000 & 952 & $4,80 \%$ & 5 & 1000 & 991 & $0,90 \%$ \\
\hline 6 & 1000 & 959 & $4,10 \%$ & 6 & 1000 & 986 & $1,40 \%$ \\
\hline 7 & 1000 & 939 & $6,10 \%$ & 7 & 1000 & 969 & $3,10 \%$ \\
\hline 8 & 1000 & 943 & $5,70 \%$ & 8 & 1000 & 951 & $4,90 \%$ \\
\hline 9 & 1000 & 936 & $6,40 \%$ & 9 & 1000 & 943 & $5,70 \%$ \\
\hline 10 & 1000 & 918 & $8,20 \%$ & 10 & 1000 & 947 & $5,30 \%$ \\
\hline 11 & 1000 & 900 & $10,00 \%$ & 11 & 1000 & 913 & $8,70 \%$ \\
\hline 12 & 1000 & 898 & $10,20 \%$ & 12 & 1000 & 879 & $12,10 \%$ \\
\hline 13 & 1000 & 0 & $100,00 \%$ & 13 & 1000 & 0 & $100,00 \%$ \\
\hline 14 & 1000 & 0 & $100,00 \%$ & 14 & 1000 & 0 & $100,00 \%$ \\
\hline \multicolumn{3}{|c|}{ Average error } & $5,20 \%$ & \multicolumn{3}{|c|}{ Average error } & $3,95 \%$ \\
\hline
\end{tabular}




\begin{tabular}{|c|c|c|c|c|c|c|c|}
\hline \multicolumn{3}{|c|}{ Forward Test } & \multicolumn{3}{c|}{ Backward Test } \\
\hline $\begin{array}{c}\text { Distance } \\
\text { (Meter) }\end{array}$ & Data Sent & $\begin{array}{c}\text { Data } \\
\text { Received }\end{array}$ & Error & $\begin{array}{c}\text { Distance } \\
\text { (Meter) }\end{array}$ & $\begin{array}{c}\text { Data } \\
\text { Sent }\end{array}$ & $\begin{array}{c}\text { Data } \\
\text { Received }\end{array}$ & Error \\
\hline \multicolumn{2}{|c|}{ Forward Accuracy } & $94,80 \%$ & \multicolumn{3}{c|}{ Backward Accuracy } & $96,05 \%$ \\
\hline
\end{tabular}

Table 3. Indoor Accuracy Test Result (Right Test and Left Test)

\begin{tabular}{|c|c|c|c|c|c|c|c|}
\hline \multicolumn{4}{|c|}{ Right $\left(45^{\circ}\right)$ Test } & \multicolumn{4}{|c|}{ Left $\left(45^{\circ}\right)$ Test } \\
\hline $\begin{array}{c}\text { Distance } \\
\text { (Meter) }\end{array}$ & Data Sent & $\begin{array}{c}\text { Data } \\
\text { Received }\end{array}$ & Error & $\begin{array}{c}\text { Distance } \\
\text { (Meter) }\end{array}$ & $\begin{array}{l}\text { Data } \\
\text { Sent }\end{array}$ & $\begin{array}{c}\text { Data } \\
\text { Received }\end{array}$ & Error \\
\hline 1 & 1000 & 1000 & $0,00 \%$ & 1 & 1000 & 1000 & $0,00 \%$ \\
\hline 2 & 1000 & 1000 & $0,00 \%$ & 2 & 1000 & 991 & $0,90 \%$ \\
\hline 3 & 1000 & 977 & $2,30 \%$ & 3 & 1000 & 983 & $1,70 \%$ \\
\hline 4 & 1000 & 981 & $1,90 \%$ & 4 & 1000 & 980 & $2,00 \%$ \\
\hline 5 & 1000 & 963 & $3,70 \%$ & 5 & 1000 & 978 & $2,20 \%$ \\
\hline 6 & 1000 & 964 & $3,60 \%$ & 6 & 1000 & 975 & $2,50 \%$ \\
\hline 7 & 1000 & 943 & $5,70 \%$ & 7 & 1000 & 958 & $4,20 \%$ \\
\hline 8 & 1000 & 939 & $6,10 \%$ & 8 & 1000 & 947 & $5,30 \%$ \\
\hline 9 & 1000 & 928 & $7,20 \%$ & 9 & 1000 & 939 & $6,10 \%$ \\
\hline 10 & 1000 & 933 & $6,70 \%$ & 10 & 1000 & 901 & $9,90 \%$ \\
\hline 11 & 1000 & 925 & $7,50 \%$ & 11 & 1000 & 894 & $10,60 \%$ \\
\hline 12 & 1000 & 935 & $6,50 \%$ & 12 & 1000 & 888 & $11,20 \%$ \\
\hline 13 & 1000 & 0 & $100,00 \%$ & 13 & 1000 & 0 & $100,00 \%$ \\
\hline 14 & 1000 & 0 & $100,00 \%$ & 14 & 1000 & 0 & $100,00 \%$ \\
\hline \multicolumn{3}{|c|}{ Average error } & $4,27 \%$ & \multicolumn{3}{|c|}{ Average error } & $4,72 \%$ \\
\hline \multicolumn{3}{|c|}{ Right $\left(45^{\circ}\right)$ Accuracy } & $95,73 \%$ & \multicolumn{3}{|c|}{ Left $\left(45^{\circ}\right)$ Accuracy } & $95,28 \%$ \\
\hline
\end{tabular}

Based on Table 1, Table 2, and Table 3, it can be concluded that the greatest accuracy value for each test occurs when the distance between the steering gear and the simulation car is 1 meter and the smallest accuracy value for each test occurs when the distance is 12 meters. The farther the distance between the transceivers, the higher the error that occurs and lowers the level of accuracy.

\subsection{Outdoor Accuracy Test Results}

The results of the accuracy test for the outdoor test are listed in Table 4, Table 5, and Table 6.

Table 4. Outdoor Accuracy Test Result (Gas Test and Brake Test)

\begin{tabular}{|c|c|c|c|c|c|c|c|}
\hline \multicolumn{4}{|c|}{ Gas Test } & \multicolumn{4}{c|}{ Brake Test } \\
\hline $\begin{array}{c}\text { Distance } \\
\text { (Meter) }\end{array}$ & Data Sent & $\begin{array}{c}\text { Data } \\
\text { Received }\end{array}$ & Error & $\begin{array}{c}\text { Distance } \\
\text { (Meter) }\end{array}$ & $\begin{array}{c}\text { Data } \\
\text { Sent }\end{array}$ & $\begin{array}{c}\text { Data } \\
\text { Received }\end{array}$ & Error \\
\hline 1 & 1000 & 1000 & $0,00 \%$ & 1 & 1000 & 1000 & $0,00 \%$ \\
\hline 2 & 1000 & 998 & $0,20 \%$ & 2 & 1000 & 1000 & $0,00 \%$ \\
\hline
\end{tabular}




\begin{tabular}{|c|c|c|c|c|c|c|c|}
\hline \multicolumn{5}{|c|}{ Gas Test } & \multicolumn{4}{c|}{ Brake Test } \\
\hline $\begin{array}{c}\text { Distance } \\
\text { (Meter) }\end{array}$ & Data Sent & $\begin{array}{c}\text { Data } \\
\text { Received }\end{array}$ & Error & $\begin{array}{c}\text { Distance } \\
\text { (Meter) }\end{array}$ & $\begin{array}{c}\text { Data } \\
\text { Sent }\end{array}$ & $\begin{array}{c}\text { Data } \\
\text { Received }\end{array}$ & Error \\
\hline 3 & 1000 & 986 & $1,40 \%$ & 3 & 1000 & 990 & $1,00 \%$ \\
\hline 4 & 1000 & 990 & $1,00 \%$ & 4 & 1000 & 994 & $0,60 \%$ \\
\hline 5 & 1000 & 988 & $1,20 \%$ & 5 & 1000 & 999 & $0,10 \%$ \\
\hline 6 & 1000 & 985 & $1,50 \%$ & 6 & 1000 & 999 & $0,10 \%$ \\
\hline 7 & 1000 & 991 & $0,90 \%$ & 7 & 1000 & 997 & $0,30 \%$ \\
\hline 8 & 1000 & 988 & $1,20 \%$ & 8 & 1000 & 989 & $1,10 \%$ \\
\hline 9 & 1000 & 985 & $1,50 \%$ & 9 & 1000 & 997 & $0,30 \%$ \\
\hline 10 & 1000 & 971 & $2,90 \%$ & 10 & 1000 & 998 & $0,20 \%$ \\
\hline 11 & 1000 & 960 & $4,00 \%$ & 11 & 1000 & 996 & $0,40 \%$ \\
\hline 12 & 1000 & 966 & $3,40 \%$ & 12 & 1000 & 997 & $0,30 \%$ \\
\hline 13 & 1000 & 591 & $40,90 \%$ & 13 & 1000 & 703 & $29,70 \%$ \\
\hline 14 & 1000 & 304 & $69,60 \%$ & 14 & 1000 & 481 & $51,90 \%$ \\
\hline 15 & 1000 & 210 & $79,00 \%$ & 15 & 1000 & 412 & $58,80 \%$ \\
\hline 16 & 1000 & 198 & $80,20 \%$ & 16 & 1000 & 204 & $79,60 \%$ \\
\hline 17 & 1000 & 169 & $83,10 \%$ & 17 & 1000 & 185 & $81,50 \%$ \\
\hline 18 & 1000 & 144 & $85,60 \%$ & 18 & 1000 & 72 & $92,80 \%$ \\
\hline 19 & 1000 & 0 & $100,00 \%$ & 19 & 1000 & 0 & $100,00 \%$ \\
\hline 20 & 1000 & 0 & $100 \%$ & 20 & 1000 & 0 & $100 \%$ \\
\hline & Average error & & $25,42 \%$ & & Average error & $22,15 \%$ \\
\hline & Gas Accuracy & & $74,58 \%$ & & Brake Accuracy & $77,85 \%$ \\
\hline
\end{tabular}

Table 5. Outdoor Accuracy Test Result (Forward Test and Backward Test)

\begin{tabular}{|c|c|c|c|c|c|c|c|}
\hline \multicolumn{5}{|c|}{ Forward Test } & \multicolumn{4}{c|}{ Backward Test } \\
\hline $\begin{array}{c}\text { Distance } \\
\text { (Meter) }\end{array}$ & Data Sent & $\begin{array}{c}\text { Data } \\
\text { Received }\end{array}$ & Error & $\begin{array}{c}\text { Distance } \\
\text { (Meter) }\end{array}$ & $\begin{array}{c}\text { Data } \\
\text { Sent }\end{array}$ & $\begin{array}{c}\text { Data } \\
\text { Received }\end{array}$ & Error \\
\hline 1 & 1000 & 1000 & $0,00 \%$ & 1 & 1000 & 1000 & $0,00 \%$ \\
\hline 2 & 1000 & 990 & $1,00 \%$ & 2 & 1000 & 1000 & $0,00 \%$ \\
\hline 3 & 1000 & 985 & $1,50 \%$ & 3 & 1000 & 990 & $1,00 \%$ \\
\hline 4 & 1000 & 991 & $0,90 \%$ & 4 & 1000 & 1000 & $0,00 \%$ \\
\hline 5 & 1000 & 989 & $1,10 \%$ & 5 & 1000 & 998 & $0,20 \%$ \\
\hline 6 & 1000 & 986 & $1,40 \%$ & 6 & 1000 & 1000 & $0,00 \%$ \\
\hline 7 & 1000 & 988 & $1,20 \%$ & 7 & 1000 & 998 & $0,20 \%$ \\
\hline 8 & 1000 & 988 & $1,20 \%$ & 8 & 1000 & 998 & $0,20 \%$ \\
\hline 9 & 1000 & 986 & $1,40 \%$ & 9 & 1000 & 998 & $0,20 \%$ \\
\hline 10 & 1000 & 980 & $2,00 \%$ & 10 & 1000 & 997 & $0,30 \%$ \\
\hline 11 & 1000 & 972 & $2,80 \%$ & 11 & 1000 & 993 & $0,70 \%$ \\
\hline 12 & 1000 & 971 & $2,90 \%$ & 12 & 1000 & 994 & $0,60 \%$ \\
\hline 13 & 1000 & 641 & $35,90 \%$ & 13 & 1000 & 581 & $41,90 \%$ \\
\hline 14 & 1000 & 412 & $58,80 \%$ & 14 & 1000 & 418 & $58,20 \%$ \\
\hline 15 & 1000 & 209 & $79,10 \%$ & 15 & 1000 & 415 & $58,50 \%$ \\
\hline
\end{tabular}

MIND - 216 


\begin{tabular}{|c|c|c|c|c|c|c|c|}
\hline \multicolumn{5}{|c|}{ Forward Test } & \multicolumn{4}{c|}{ Backward Test } \\
\hline $\begin{array}{c}\text { Distance } \\
\text { (Meter) }\end{array}$ & Data Sent & $\begin{array}{c}\text { Data } \\
\text { Received }\end{array}$ & Error & $\begin{array}{c}\text { Distance } \\
\text { (Meter) }\end{array}$ & $\begin{array}{c}\text { Data } \\
\text { Sent }\end{array}$ & $\begin{array}{c}\text { Data } \\
\text { Received }\end{array}$ & Error \\
\hline 16 & 1000 & 201 & $79,90 \%$ & 16 & 1000 & 228 & $77,20 \%$ \\
\hline 17 & 1000 & 178 & $82,20 \%$ & 17 & 1000 & 108 & $89,20 \%$ \\
\hline 18 & 1000 & 145 & $85,50 \%$ & 18 & 1000 & 69 & $93,10 \%$ \\
\hline 19 & 1000 & 0 & $100,00 \%$ & 19 & 1000 & 0 & $100,00 \%$ \\
\hline 20 & 1000 & 0 & $100,00 \%$ & 20 & 1000 & 0 & $100,00 \%$ \\
\hline \multicolumn{3}{|c|}{ Average error } & $24,38 \%$ & \multicolumn{3}{c|}{ Average error } & $23,42 \%$ \\
\hline \multicolumn{3}{|c|}{ Forward Accuracy } & $75,62 \%$ & \multicolumn{6}{c|}{ Backward Accuracy } & $76,58 \%$ \\
\hline
\end{tabular}

Table 6. Outdoor Accuracy Test Result (Right Test and Left Test)

\begin{tabular}{|c|c|c|c|c|c|c|c|}
\hline \multicolumn{5}{|c|}{ Right (45 ${ }^{\circ}$ Test } & \multicolumn{5}{c|}{ Left (45 ${ }^{\circ}$ Test } \\
\hline $\begin{array}{c}\text { Distance } \\
\text { (Meter) }\end{array}$ & Data Sent & $\begin{array}{c}\text { Data } \\
\text { Received }\end{array}$ & Error & $\begin{array}{c}\text { Distance } \\
\text { (Meter) }\end{array}$ & $\begin{array}{c}\text { Data } \\
\text { Sent }\end{array}$ & $\begin{array}{c}\text { Data } \\
\text { Received }\end{array}$ & Error \\
\hline 1 & 1000 & 1000 & $0,00 \%$ & 1 & 1000 & 1000 & $0,00 \%$ \\
\hline 2 & 1000 & 998 & $0,20 \%$ & 2 & 1000 & 1000 & $0,00 \%$ \\
\hline 3 & 1000 & 992 & $0,80 \%$ & 3 & 1000 & 1000 & $0,00 \%$ \\
\hline 4 & 1000 & 1000 & $0,00 \%$ & 4 & 1000 & 999 & $0,10 \%$ \\
\hline 5 & 1000 & 997 & $0,30 \%$ & 5 & 1000 & 1000 & $0,00 \%$ \\
\hline 6 & 1000 & 999 & $0,10 \%$ & 6 & 1000 & 1000 & $0,00 \%$ \\
\hline 7 & 1000 & 970 & $3,00 \%$ & 7 & 1000 & 999 & $0,10 \%$ \\
\hline 8 & 1000 & 974 & $2,60 \%$ & 8 & 1000 & 991 & $0,90 \%$ \\
\hline 9 & 1000 & 963 & $3,70 \%$ & 9 & 1000 & 968 & $3,20 \%$ \\
\hline 10 & 1000 & 973 & $2,70 \%$ & 10 & 1000 & 983 & $1,70 \%$ \\
\hline 11 & 1000 & 981 & $1,90 \%$ & 11 & 1000 & 993 & $0,70 \%$ \\
\hline 12 & 1000 & 980 & $2,00 \%$ & 12 & 1000 & 991 & $0,90 \%$ \\
\hline 13 & 1000 & 438 & $56,20 \%$ & 13 & 1000 & 830 & $17,00 \%$ \\
\hline 14 & 1000 & 391 & $60,90 \%$ & 14 & 1000 & 375 & $62,50 \%$ \\
\hline 15 & 1000 & 356 & $64,40 \%$ & 15 & 1000 & 210 & $79,00 \%$ \\
\hline 16 & 1000 & 208 & $79,20 \%$ & 16 & 1000 & 108 & $89,20 \%$ \\
\hline 17 & 1000 & 108 & $89,20 \%$ & 17 & 1000 & 94 & $90,60 \%$ \\
\hline 18 & 1000 & 82 & $91,80 \%$ & 18 & 1000 & 63 & $93,70 \%$ \\
\hline 19 & 1000 & 0 & $100,00 \%$ & 19 & 1000 & 0 & $100,00 \%$ \\
\hline 20 & 1000 & 0 & $100,00 \%$ & 20 & 1000 & 0 & $100,00 \%$ \\
\hline & Average error & & $25,50 \%$ & & Average error & $24,42 \%$ \\
\hline & & & $74,50 \%$ & & Left $\left(45^{\circ}\right)$ Accuracy & $75,58 \%$ \\
\hline
\end{tabular}

Based on Table 4, Table 5, and Table 6, it can be concluded that the greatest accuracy value for each test occurs when the distance between the transmitter and the receiver is 1 meter and the smallest accuracy value for each test occurs when the distance is 18 meters.

\subsection{Indoor Qos Test Results}

The results of the Quality of Service test for the indoor test are listed in Table 7. 
Table 7. Indoor QoS Test Result

\begin{tabular}{|c|c|c|c|c|}
\hline $\begin{array}{c}\text { Distance } \\
\text { (Meter) }\end{array}$ & $\begin{array}{c}\text { Throughput } \\
(\mathbf{K b} / \mathbf{s})\end{array}$ & $\begin{array}{c}\text { Packet Loss } \\
\mathbf{( \% )}\end{array}$ & $\begin{array}{c}\text { Delay } \\
\mathbf{( m s )}\end{array}$ & $\begin{array}{c}\text { Jitter } \\
(\mathbf{m s})\end{array}$ \\
\hline 1 & 59,82 & 0,00 & 16,72 & 16,72 \\
\hline 3 & 59,52 & 2,63 & 16,80 & 17,24 \\
\hline 6 & 59,58 & 2,93 & 16,78 & 17,29 \\
\hline 9 & 59,70 & 6,05 & 16,75 & 17,87 \\
\hline 12 & 59,58 & 10,28 & 16,78 & 18,73 \\
\hline 15 & 0,00 & 100,00 & 100.00 & 1000,00 \\
\hline 18 & 0,00 & 100,00 & 100.00 & 1000,00 \\
\hline
\end{tabular}

Based on Table 7, QoS measurements for each different distance in the room get varying values, namely the throughput value has an average value of $59.64 \mathrm{~Kb} / \mathrm{s}$, the packet loss value has an average value of $4.38 \%$, the delay value has an average value of $16.77 \mathrm{~ms}$ and the jitter value has an average value of $17.56 \mathrm{~ms}$. Referring to the classification based on the TIPHON version (Pamungkas, Kusrini, \& Pramono, 2018), the throughput parameter is in the "bad" category with a throughput index of 1 , the packet loss parameter is in the "good" category with a packet loss index of 3 . The delay parameter is in the "very good" category with a delay index of 4 The jitter parameter is in the "very good" category with a delay index of 4 . Figure 11 is a comparison of the results of QoS for indoor.

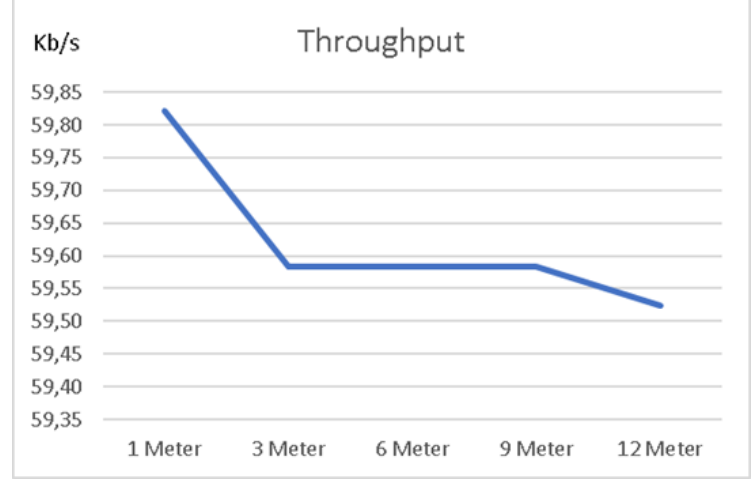

(a)

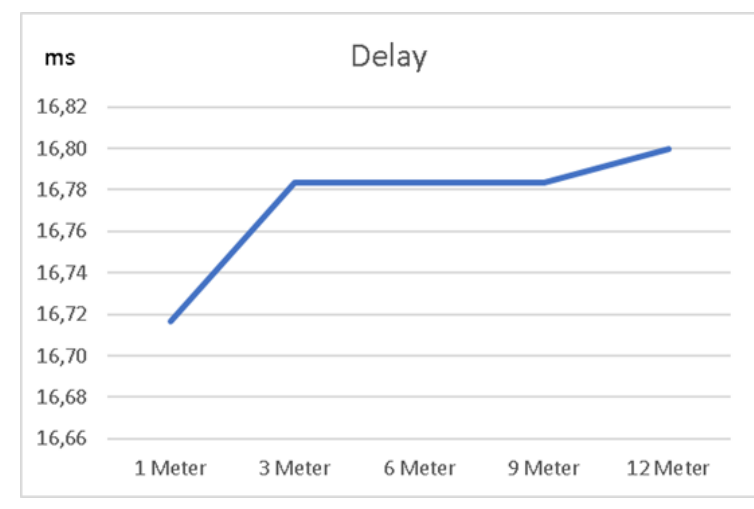

(c)

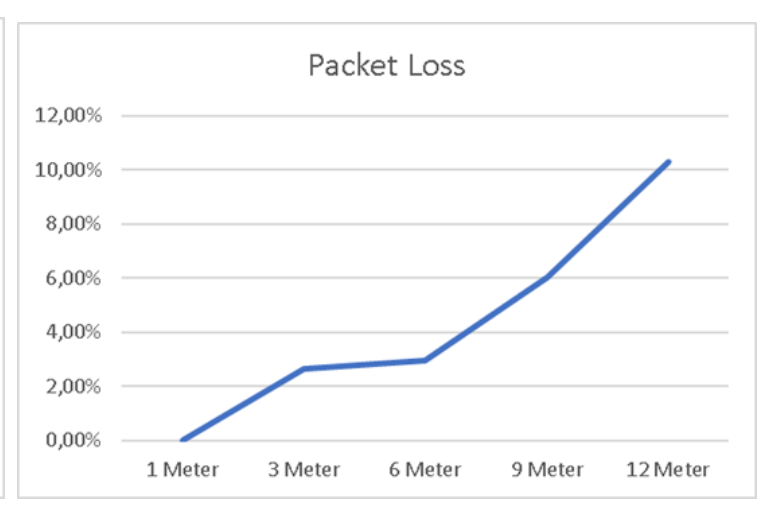

(b)

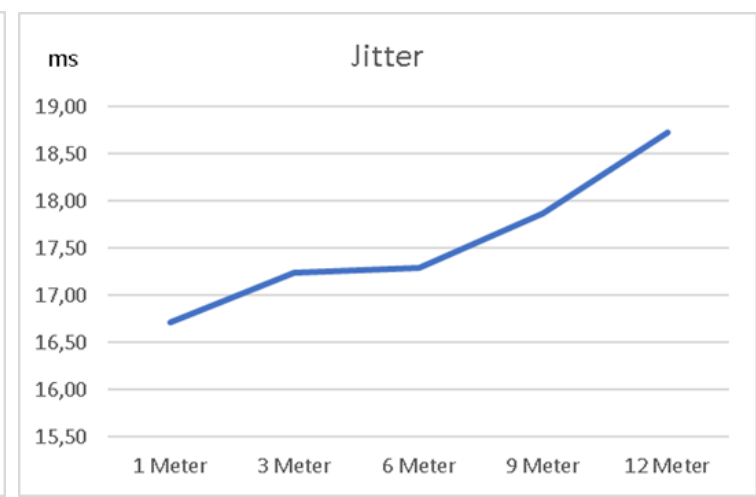

(d)

Figure 11. Comparison QoS Indoor (a) Throughput (b) Packet Loss (c) Delay (d) Jitter

\subsection{Outdoor QoS Test Results}

The results of the Quality of Service test for the outdoor test are listed in Table 8. 
Table 8. Outdoor QoS Test Result

\begin{tabular}{|c|c|c|c|c|}
\hline $\begin{array}{c}\text { Distance } \\
\text { (Meter) }\end{array}$ & $\begin{array}{c}\text { Throughput } \\
(\mathbf{K b} / \mathbf{s})\end{array}$ & $\begin{array}{c}\text { Packet Loss } \\
\mathbf{( \% )}\end{array}$ & $\begin{array}{c}\text { Delay } \\
\mathbf{( m s )}\end{array}$ & $\begin{array}{c}\text { Jitter } \\
\mathbf{( m s )}\end{array}$ \\
\hline 1 Meter & 59,70 & $0,00 \%$ & 16,75 & 16,75 \\
\hline 3 Meter & 59,58 & $0,95 \%$ & 16,78 & 16,95 \\
\hline 6 Meter & 59,64 & $0,52 \%$ & 16,77 & 16,86 \\
\hline 9 Meter & 59,76 & $1,72 \%$ & 16,73 & 17,03 \\
\hline 12 Meter & 59,64 & $1,68 \%$ & 16,77 & 17,06 \\
\hline 15 Meter & 40,49 & $69,80 \%$ & 24,70 & 81,83 \\
\hline 18 Meter & 29,41 & $90,42 \%$ & 34,00 & 355,40 \\
\hline 21 Meter & 0,00 & $100,00 \%$ & 100.00 & 1000,00 \\
\hline 24 Meter & 0,00 & $100,00 \%$ & 100.00 & 1000,00 \\
\hline
\end{tabular}

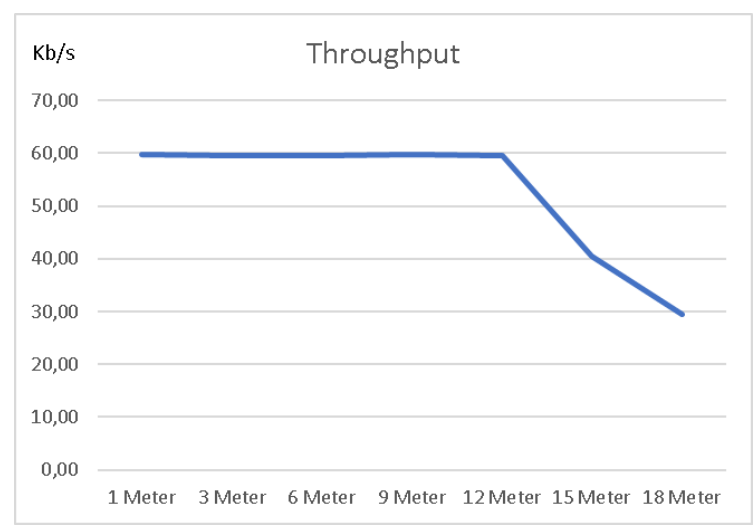

(a)

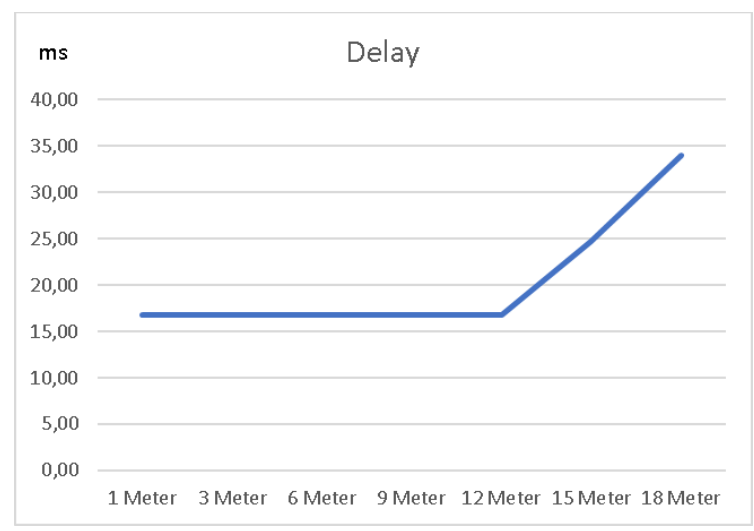

(c)

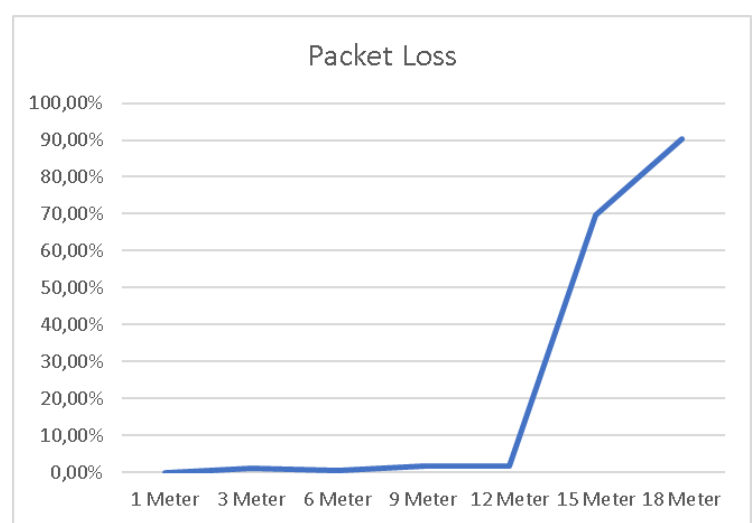

(b)

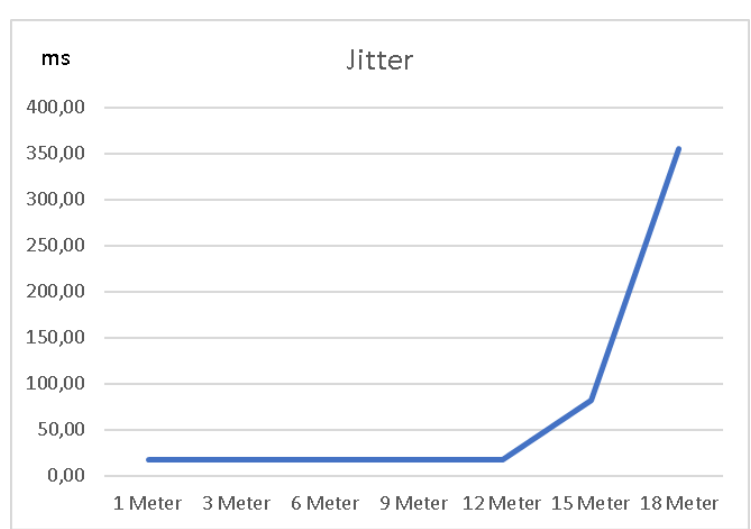

(d)

Figure 12. Comparison QoS Outdoor (a) Throughput (b) Packet Loss (c) Delay (d) Jitter

Based on Table 8, QoS measurements for outdoor get varied results such as measurements for indoor, namely the throughput value has an average value of $52.6 \mathrm{~Kb} / \mathrm{s}$, the packet loss value has an average value of $23,58 \%$, the delay value has an average value of $20.36 \mathrm{~ms}$ and the jitter value has an average value of $74.55 \mathrm{~ms}$. Referring to the classification based on the TIPHON version, the throughput parameter is in the "bad" category with a throughput index of 1 , the packet loss parameter is in the "bad" category with a packet loss index of 1 . The delay parameter is in the "very good" category with a delay index of 4 The jitter parameter is included in the "very good" category with a delay index of 4 . Figure 12 is a comparison of the results of QoS for outdoor. 
Based on the results of indoor and outdoor testing, it can be concluded that the barrier between the transmitter and the receiver can affect wireless communication. In indoor testing, wireless communication can only be carried out with a maximum distance of 12 meters and when the distance between the transmitter and receiver is more than 12 meters, the receiver cannot receive data. As for outdoor testing, transceivers can communicate with each other with a maximum distance of 18 meters and when the distance between the transmitter and receiver is more than 18 meters, the receiver cannot receive data.

\section{CONCLUSION}

This study aims to observe and evaluate the accuracy and the Quality of Service that occurs when sending data wirelessly using NRF24L01 on a driving simulator. During indoor and outdoor testing, the error rate increases when the transmitter is farther away from the receiver, causing the accuracy level to decrease. The Quality of Service that occurs has varying values. For throughput testing, the average value of indoor testing is $59.64 \mathrm{~Kb} / \mathrm{s}$ in the "bad" category, while the average value for outdoor testing is $52.6 \mathrm{~Kb} / \mathrm{s}$ in the "bad" category. For packet loss testing, the average value of indoor testing is $4.38 \%$ in the "good" category, while the average value for outdoor testing is $23.58 \%$ in the "bad" category. For the delay test, the average value of the indoor test is $0.01667 \mathrm{~s}$, while the average value of the outdoor test is $0.02036 \mathrm{~s}$ with the delay category for indoor and outdoor is "very good". Then for the jitter test, the average value of the indoor test is $0.0176 \mathrm{~ms}$ with the "very good" category, while the average value of the outdoor test is $0.0746 \mathrm{~ms}$ with the "very good" category. Overall, it can be concluded that obstructions and distance between transceivers will affect the performance of wireless communication. In addition, the right equipment, assembly, and source code can minimize the occurrence of errors and can maximize the performance of the transmitter in sending data or the receiver in receiving data.

\section{REFERENCES}

Ali, K. A., \& Mouftah, H. T. (2011). Wireless personal area networks architecture and protocols for multimedia applications. Ad Hoc Networks, 9(4), 675-686. https://doi.org/10.1016/j.adhoc.2010.09.006

Basak, M., \& Sen, P. S. (2017). An Overview of Wireless Local Area Networks and Security System. International Journal of Advanced Engineering, Management and Science, 3(2), 63-66. https://doi.org/10.24001/ijaems.3.2.11

Desman R., Crisandolin., Hannats H.I., Mochammad, S.B., A. (2018). Implementasi Wireless

Sensor Network Pada Keamanan Rumah Menggunakan Sensor Pir. Jurnal Pengembangan Teknologi Informasi Dan IImu Komputer (J-PTIIK) Universitas Brawijaya, 2(12), 7322-7330.

Fajriansyah, B., Ichwan, M., \& Susana, R. (2018). Evaluasi Karakteristik XBee Pro dan nRF24L01+ sebagai Transceiver Nirkabel. ELKOMIKA: Jurnal Teknik Energi Elektrik, Teknik Telekomunikasi, \& Teknik Elektronika, 4(1), 83. 
Wireless Personal Area Network Performance Evaluation On Driving Simulator Realization

https://doi.org/10.26760/elkomika.v4i1.83

Fitri, F., \& Setiawan, Y. (2015). Rancang Bangun Buka Tutup Pintu Pagar Rumah Menggunakan Remote Control Wireless Rf315. Jurnal Sisfokom (Sistem Informasi Dan Komputer), 4(2), 49. https://doi.org/10.32736/sisfokom.v4i2.197

Kurnia, Wisma D., Munadi, Rendy., Bisono, G. (2018). Comparison Analysis Of Zigbee And 2.4 Ghz Rf Communication Protocol On Implementation Of Vehicle Traffic Information System Based On Wireless Sensor Network. 5(3), 4489-4495.

Kurniadi, Yohan. Liliana, L., \& Radion Purba, K. (2016). Pembuatan Aplikasi Simulasi Ujian Praktik Pengambilan Surat Izin Mengemudi Kendaraan Roda Empat. Jurnal Infra, 4(2), 110-115.

Kusriyanto, M., \& Wismoyo, N. (2017). Sistem palang pintu perlintasan kereta api otomatis dengan komunikasi. Teknoin, 23(1), 73-80.

Lasagani, K. A. T. (2018). A Communication Method for Remote Control of Grid-tied Converters.

Manru, Eko Prasetyo, F. (2016). Analisa Kinerja Jaringan W-LAN Pada Perangkat Access Point 802.11/g.

Pamungkas, S. W., Kusrini, \& Pramono, E. (2018). Analisis Quality of Service (QoS) Pada Jaringan Hotspot SMA Negeri XYZ. E-Jurnal JUSITI (Jurnal Sistem Informasi Dan Teknologi Informasi), 7-2(2), 142-152. https://doi.org/10.36774/jusiti.v7i2.249

Pranata, Y. A., Fibriani, I., \& Utomo, S. B. (2016). Analisis Optimasi Kinerja Quality of Service Pada Layanan Komunikasi Data Menggunakan Ns-2 Di Pt. Pln (Persero) Jember. Sinergi, 20(2), 149. https://doi.org/10.22441/sinergi.2016.2.009

Rasudin. (2014). Quality of Services (Qos) Pada Jaringan Internet Dengan Metode Hierarchy Token Bucket. Jurnal Penelitian Teknik Informatika Universitas Malikussaleh, 4(1), 210223.

Sumarjono, A. (2018). Perancangan Prototype Lampu Rumah Tangga Via Wireless Bluetooth 2,4 Ghz Berbasis Arduino. 1(1), 9-20.

Wulandari, Pipit., Soim, Sopian., Rose, M. (2017). Monitoring Dan Analisis QoS (Quality of Service) Jaringan Internet pada Gedung KPA Politeknik Negeri Sriwijaya dengan Metode Drive Test. 341-347. 